\title{
WAWACAN SITI PERMANA KARYA M.K. MANGOENDIKARIA (Kajian Struktural dan Antropologi Sastra)
}

\author{
Egi Praja Septian \\ SMPN 4 Kota Baru \\ Pos-el: egiprajaseptian@gmail.com
}

\begin{abstract}
Abstrak
Penelitian ini berjudul Wawacan Siti Permana Karya M.K. Mangoendikaria (Kajian Struktural dan Antropologi Sastra). Penelitian ini bertujuan mendeskripsikan: 1) struktur formal Wawacan Siti Permana, 2) struktur naratif Wawacan Siti Permana, 3) unsur-unsur antropologi sastra dalam Wawacan Siti Permana. Sumber data dari penelitian ini adalah Wawacan Siti Permana yang ditulis oleh M.K. Mangoendikaria. Metode penelitian yang digunakan adalah metode deskriptif. Teknik penelitian yang digunakan adalah teknik studi pustaka. Wawacan Siti Permana menceritakan sosok wanita yang cantik, bernama Nyi Siti Permana, selaku anak dari lurah désa Cigéréléng, banyak pria yang terpikat olehnya. Pupuh yang ditemukan terdapat 10 pupuh dengan 526 paragraf, yaitu pupuh dangdanggula, pupuh asmarandana, pupuh kinanti, pupuh pangkur, pupuh magatru, pupuh sinom, pupuh mijil, pupuh maskumambang, pupuh lambang, dan pupuh pucung. Hasil dari penelitian ini adalah: 1) struktur formal Wawacan Siti Permana terdiri dari guru lagu dan guru wilangan pupuh, watak/karakter pupuh, serta sepuluh sasmita pupuh, 2) struktur naratif Wawacan Siti Permana meliputi: a) alur cerita campuran dan ada 18 episode, b) terdapat lima motif cerita, c) tokoh cerita terdiri dari 12 tokoh, d) latar cerita meliputi latar tempat, latar waktu, dan latar suasana, e) tema cerita dalam Wawacan Siti Permana yaitu kasih sayang, f) terdapat kolofon yaitu pada jaman perang Itali dan Absinia, dan g) tidak ditemukan adanya manggalasastra, 3) unsur antropologi sastra Wawacan Siti Permana meliputi: a) sistem kepercayaan (religi) meliputi tiga aspek, b) organisasi sosial/organisasi kemasyarakatan meliputi dua aspek, c) ilmu pengetahuan terdiri dari delapan aspek, d) bahasa meliputi tiga bahasa, gaya bahasa, dan babasan paribasa Sunda, e) terdapat empat kesenian, f) sistem mata pencaharian terdapat 16 mata pencaharian, g) sistem tekhnologi meliputi enam aspek. Wawacan Siti Permana mempunyai banyak nilai-nilai didalamnya dan sangat penting untuk kekayaan kebudayaan hususnya untuk masyarakat Sunda.
\end{abstract}

Kata kunci: Wawacan, Struktural, dan Antropologi Sastra

\section{WAWACAN SITI PERMANA OF M.K. MANGOENDIKARIA (a Structural and Anthropological Literature Study)}

\begin{abstract}
This research is entitled Wawacan Siti Permana of M.K. Mangoendikaria (A Structural and Anthropological Literature Study). This study aimed to describe (1) the formal structure; (2) the narrative structure; and (3) the elements of the anthropological literature in Wawacan Siti Permana. The data source of this research is the text of Wawacan Siti Permana of M.K. Mangoendikaria. The research employed descriptive method. This study used the technique of literature study. Wawacan Siti Permana tells a story of a beautiful woman, named Nyi Siti Permana. She is the daughter of the Head of Cigereleng Village. Many men are lured by Siti Permana. In the text, there are 10 pupuhs with 526 paragraphs. They are Pupuh dangdanggula, Pupuh Asmarandana, Pupuh kinanti, Pupuh Pangkur, Pupuh Magatru, Pupuh
\end{abstract}


Sinom Pupuh Mijil, Pupuh Maskumambang, Pupuh Lambang, and Pupuh Pucung. There are some of the results of this research. (1) The formal structure of Wawacan Siti Permana consists of guru lagu and guru wilangan of the pupuhs, characters of the pupuhs, and ten sasmitas of the pupuhs. (2) the narrative structure of Wawacan Siti Permana includes (a) a mixture storyline with 18 episodes; (B) five motifs of story; $(C) 12$ characters of the stories; $(D)$ the background of place, time setting, and background of ambience; (E) the theme of compassion; $(F)$ The colophon of days of the war between Italy and Ethiopia; and $(g)$ no manggalasastra. (3) The elements of anthropological literature are (a) the three aspects of the belief system (religion); (b) two aspects of social organization; $(C)$ the eight aspects of science; $(D)$ three languages, style, and Sundanese babasan-paribasa; $(E)$ four arts; $(F) 16$ livelihood; $(G)$ six aspects of technological systems. Wawacan Siti Permana contains many important values and cultural wealth of the Sundanese people.

Keywords: Wawacan, Structure, and Anthropological Literature

\section{PENDAHULUAN}

Karya sastra merupakan salah satu unsur dari kebudayaan yang mengandung nilai keindahan dan bisa menimbulkan berbagai rasa, pikiran, dan pengetahuan serta mamiliki manfaat yang bisa mempengaruhi jiwa pembacanya. Karya sastra juga merupakan gambaran gejala sosial yang berkaitan dengan peraturan adat istiadat serta dapat menjadi dokumen yang penting untuk menelaah sejarah sosial pada setiap jamannya.

Karya sastra tidak jauh berbeda dengan kenyataan, yang menceritakan dan menggambarkan tentang kebudayaan. Karya sastra juga bisa menunjukkan gambaran mengenai kehidupan. Karya sastra dan masyarakat merupakan hal yang saling berkaitan, karena didalamnya tergambar kehidupan manusia serta budaya yang diwakili oleh tokoh-tokoh fiksi (Istiqomah, 2015, hal. 2). Karya sastra selaku tanda yang saling berkaitan dengan konvensi masyarakatnya. Karya sastra tidak lepas dari sejarah dan latar sosial budaya masyarakat yang menciptakannya (Pradopo, 2001, hal. 56).

Sastra dan masyarakat merupakan hal yang saling berhubungan. Sastra bisa menunjukkan tema-tema tentang keadaan sosial budaya masyarakat. Dalam kehidupan sehari-hari, manusia hidup pada aturan sistem keyakinan, peraturan- peraturan, norma-norma serta petunjukpetunjuk yang semuanya muncul secara alamiah atau dibuat oleh manusianya sebagai kebutuhan dari kebudayaannya, karena budaya tidak bisa dipisahkan dari kehidupan manusia (Astutik, 2012, hal. 2). Pengarang dalam menciptakan karya sastra itu dengan melalui imajinasi yang tentunya dipengaruhi oleh keadaan lingkungannya, walaupun keadaan lingkungan tidak mutlak ada pada karya sastra (Ahmadi, 2010, hal. 40).

Sebelum masyarakat Sunda mengenal bentuk karya sastra prosa, karya sastra yang lebih dulu muncul salah satunya adalah wawacan. Wawacan termasuk karya sastra dalam bentuk tertulis. Bentuk tulisan yang disusun dalam puisi wawacan itu ditembangkan (didangdingkeun) menggunakan aturan pupuh. Dilihat dari bahasanya, selain dari bahasa Sunda, juga terdapat bahasa Indonesia, bahasa Jawa, dan bahasa Jawa.

Menurut Rosidi dalam Koswara (2011, hal. 131), wawacan adalah hikayat yang ditulis pada bentuk puisi yang dinamai dangding. Dangding adalah sekumpulan tertentu yang menggambarkan hal-hal yang tertentu juga. Dangding dibentuk oleh beberapa puisi yang disebut pupuh.

Wawacan merupakan karangan panjang yang disusun pada bentuk pupuh. 
Pupuh yang digunakan berbeda-beda sesuai dengan gambaran unsur-unsur cerita seperti pelaku, latar, dan galur cerita. Oleh karena itu, isi dari wawacan itu ngalalako (Sudaryat, dkk. 2007, hal. 109).

Sekarang ini, wawacan kurang mendapatkan apresiasi dan eksistensinya di masyarakat. Menurut Mahmud (1987, hal. 90), wawacan Jawa dan Sunda menjadi merana karena unsur pementasannya yang jarang dan hampir punah, sedangkan aspek sastranya masih bisa dikonservasi melewati tulisan. Seni beluk yang hampir punah di Pasundan secara langsung menghilangkan seni penembangan wawacan, karena beluk merupakan wahana aktualisasi dari penembangan wawacan itu. Moriyama (2013, hal. 66-67), menyebutkan pada penutur bahasa Sunda, wawacan sudah jarang dibaca, apalagi ditembangkan. Hanya orang tua yang sering membaca, tapi hampir tidak pernah didangdingkeun didepan banyak orang, kecuali dari beluk dan tembang Sunda.

Wawacan termasuk kearifan lokal dan jadi kekayaan kebudayaan terutama untuk masyarakat Sunda, selain dari warisan orang tua, wawacan sangat penting untuk dijaga dan dipahami nilai-nilainya. Karena menurut Geertz dina Putranto (2003, hal. 231), suatu masyarakat walaupun tidak hidup sejalan dengan pendahulunya, tetapi secara tidak langsung akan terpengaruh oleh para pendahulunya. Istiqomah (2015, hal. 2), mengatakan kearifan lokal memberikan kontribusi pada kebudayaan yang lebih luas lagi. Misalnya, manusia bisa memanfaatkan kearifan lokal, artinya sama dengan menghormati terhadap budaya leluhur. Manusia dan budaya tidak bisa dipisahkan, di setiap tempat tinggalnya, akan tedapat kebudayaan juga disitu. Suhartono (2010, hal. 306), mengatakan bahwa masyarakat mencari cara untuk mengatasi persoalan atau konflik yang ada pada sosial-budaya dengan cara mengeluarkannya melalui cerita, hal itu dilakukan karena munculnya ketidaksadaran antropologis.

Generasi penerus jaman sekarang lebih mengetahui terhadap cerita Romeo and Juliet dari pada cerita di daerahnya sendiri, seperti pada orang Sunda, padahal cerita rakyat seperti wawacan merupakan gambaran kejadian masyarakat, walaupun tidak nyata tapi itu merupakan proyeksi dari harapan masyarakat, serta digunakan untuk mengatur adat-budaya, nilai-nilai dan norma masyarakatnya. Cerita pada wawacan sekarang sudah jarang dibaca lagi oleh generasi penerusnya. Berkembangnya jaman sudah merubah sastra dan kehidupan. Perlu diketahui bahwa pada wawacan, selain dari membaca cerita, terdapat juga ngadangding atawa tembang yang merupakan stimulus untuk mengembangkan respon motorik. Pada bidang pendidikan menurut Moriyama (2013, hal. 51), sampai pada abad ke-19, Belanda menyimpulkan bahwa dangding adalah bentuk tulisan favorit pada penutur bahasa Sunda, karena dianggap merupaka alat yang efektif untuk menyampaikan bahan pelajaran barudak Sunda.

Menurut Belanda tentang apa yang sebaiknya dimasukkan dalam pengajaran bahasa Sunda yaitu Legenda-legenda Sunda sebagai bahan bacaan, bacaan tentang adat-adat lokal, tatakrama, dan puisi Sunda (tembang). Belajar berbagai macam irama, yang berarti juga harus belajar membaca atau lebih baik lagi menyanyikan puisi, bukanlah sesuatu hal yang berlebihan dan tentu saja menarik bagi orang Sunda; pengetahuan mengenai hal itu dianggap sebagai simbol peradaban dan pendidikan yang bagus (AVSS dalam Moriyama, 2013, hal. 51).

Melihat dari perkembangan dan perubahan dari masyarakat Sunda, penelitian mengenai wawacan merupakan kegiatan khusus selain untuk memperluas dan menghidupkan kembali khasanah kesusastraan Sunda, salah satunya melalui 
pandangan antropologi sastra, fungsinya untuk mendalami, menjaga, menjelaskan dan memperkaya pandangan manusia mengenai kehidupan.

Pada wawacan yang bahannya dari kejadian modern dan realistis, Wawacan Siti Permana sangat menarik untuk dijadikan penelitian sastra, misalnya bisa dilihat dari banyaknya hal yang mirip dari unsur-unsur cerita Wawacan Siti Permana (M.K. Mangundikaria) dan beberapa unsur dari novel Yuhana (Ahmad Basah), atau beberapa unsur dari Wawacan Pipilih Nyiar nu Leuwih (R. Candrapraja) dan novel Lain Éta karya Moh. Ambri. Buku tersebut sebagian terbit sebelum perang (Mahmud, 1987, hal. 87).

Dari penelitian mengenai naskah Sunda terutama wawacan, belum ada yang meneliti mengenai Wawacan Siti Permana (WSP), padahal wawacan ini sangat penting untuk dipelajari karena salain dari kekayaan khasanah Sunda, banyak nilainilai yang penting untuk diketahui oleh masyarakat. Ada beberapa hal yang dianalisis dari penelitian Wawacan Siti Permana ini, di antaranya struktur dan antropologi sastra. oleh karena itu, penelitian ini diberi judul "Wawacan Siti Permana anggitan M.K Mangoendikaria (Ulikan Struktural jeung Antropologi Sastra).”

\section{METODE}

Metodologi yang digunakan pada penelitian ini adalah metode deskriptif. Nazir (2005: hal. 54) menyebutkan bahwa metode déskriptif adalah suatu métode dalam meneliti status sekelompok manusia, suatu objek, suatu set kondisi, suatu sistem pemikiran ataupun suatu kelas peristiwa pada masa sekarang. Tujuan dari penelitian deskriptif ini adalah untuk membuat deskripsi, gambaran atau lukisan secara sistematis, faktual dan aktual mengenai fakta-fakta, sifat-sifat serta hubungan antar fenomena yang diselidiki. Metode ini untuk mendeskripsikan fakta- fakta, sipat serta keterkaitan variabel yang diteliti, secara sistematis dan jelas. Artinya memberi gambaran yang jelas mengenai struktur dan antropologi sastra pada Wawacan Siti Permana.

Tekhnik penelitian ini adalah telaah pustaka. Tekhnik telaah pustaka artinya menyimpulkan teori-teori yang digunakan sebagai bahan tulisan untuk dijadikan pedoman pada penelitian (Suyatna, 2002, hal. 19). Menurut Sukmadinata (2012, hal. 10), talaah pustaka merupakan kegiatan memahami teori-teori dasar mengenai penelitian pada ilmu yang diteliti atau metodologi penelitiannya. Langkahlangkah telaah pustaka pada penelitian ini, yaitu: 1) membaca Wawacan Siti Permana; 2) memberi ciri struktur formal dan struktur naratif Wawacan Siti Permana; 3) memberi ciri data yang berkaitan dengan antropologi sastra; 4) memasukkan data yang telah diberi ciri agar mempermudah menganalisisnya.

\section{HASIL DAN PEMBAHASAN}

Wawacan Siti Permana menceritakan seorang wanita yang cantik dan juga baik hati, hingga banyak lelaki yang menyukai, hanya saja ada yang membawanya kea rah yang tidak baik, yaitu Tanu yang telah menggunakan asihan agar Permana jatuh cinta padanya, tetapi pada akhirnya cinta suci yang telah membuat Permana sadar, dan akhirnya menikah dengan Prawira.

Pupuh yang terdapat pada Wawacan Siti Permana (Mangoendikaria, 2009) ditemukan berjumlah 10 pupuh dan 526 paragraf, yaitu: 1) pupuh dangdanggula, 2) pupuh asmarandana, 3) pupuh kinanti, 4) pupuh pangkur, 5) pupuh magatru, 6) pupuh sinom, 7) pupuh mijil, 8) pupuh maskumambang, 9) pupuh lambang, dan 10) pupuh pucung.

\section{Pembahasan Struktur Formal}

Pembahasan mengenai struktur formal pada Wawacan Siti Permana, meliputi: a) 
guru lagu dan guru wilangan, b) watek/karakter pupuh, c) sasmita pupuh.

Guru lagu dan guru wilangan: pupuh yang sesuai dengan aturan guru lagu dan guru wilangan adalah pupuh maskumambang dan pupuh lambang. Sedangkan pupuh yang tidak sesuai dengan aturan guru lagu dan guru wilangan adalah pupuh dangdanggula, pupuh sinom, pupuh asmarandana, pupuh kinanti, pupuh pangkur, pupuh magatru, pupuh mijil, dan pupuh pucung.

Watek/karakter pupuh: pupuh dangdanggula menggambarkan watek yang gembira, pupuh sinom menggambarkan watek yang sedang gembira dan asmara, pupuh asmarandana menggambarkan watek yang sedang kasmaran atau cinta kasih, pupuh kinanti menggambarkan watek yang sedang menanti-nanti, pupuh pangkur menggambarkan watek lalampahan atau ambek, pupuh magatru menggambarkan watek yang sedang sedih, pupuh mijil menggambarkan watek kesedihan, pupuh pucung menggambarkan watek memberi nasihat atau pépéling, pupuh maskumambang menggambarkan watek yang sedih, dan pupuh lambang menggambarkan watek yang lucu atau bercanda.

Sasmita pupuh: Sasmita pupuh dangdanggula adalah manis dan mamanisna, sasmita pupuh sinom adalah aranom dan sinom, sasmita pupuh asmarandana adalah kasmaran, sasmita pupuh kinanti adalah kinanti, gumusti dan dikanti, sasmita pupuh magatru adalah magatru, sasmita pupuh pangkur adalah kapungkur-pungkur, tukang, dan tukangtukang, sasmita pupuh mijil adalah bijil, sasmita pupuh pucung adalah mucung, sasmita pupuh maskumambang adalah kumambang, dan sasmita pupuh lambang adalah lambang.

\section{Pembahasan Struktur Naratif}

Struktur naratif pada Wawacan Siti Permana meliputi tema cerita, galur cerita, motif cerita, tokoh cerita, latar cerita, manggalasastra dan kolofon. Tema cerita pada Wawacan Siti Permana yaitu mengenai kasih sayang (kaasih). Galur cerita pada Wawacan Siti Permana adalah galur campuran dan terdapat 18 episode. Motif cerita pada Wawacan Siti Permana adalah motif wasiat, motif nikah, motif babaran, motif lalampahan, dan motif pipisahan. Tokoh pada Wawacan Siti Permana adalah Siti Permana, Mas Prawira, Radén Tanu, Nyi Rohani, Agus Karimin, Endén Cicih, Juragan Demang, Nyi Demang, Ki Abdulkarim, Lurah jeneng, Nyi Lurah, jeung Ki Adul. Latar cerita pada Wawacan Siti Permana meliputi latar tempat, latar waktu, dan latar suasana. Latar tempat berada di Désa Cigéréléng, gunung Halimun, leuweung, walungan, kamar, lembur, dapur, palataran, bumi, kebon, kelurahan, dan tepas. Latar waktu pada Wawacan Siti Permana adalah waktu pada sapoésapeuting, waktu berdasarkan pada lamanya (durasi) dan istilah waktu lainnya. Latar suasana pada Wawacan Siti Permana adalah prihatin, raripuh, ceurik/ careurik, sedih/kasedih, nangis, susah, ma'mur, nyaah, asih/mikaasih, bungah/bingah, kasmaran, atoh, bogoh, bingbang, sono, tunggara, tunduh, bendu, senang, timburu, iklas, satengah gélo, hulang-huleng, tagiwur, panasaran, ijid, geuleuh, ngéwa, sono, pusing, melas, teu éling, ambek, édan, bingung, kangen, cageur, waas/wararaas, lara, nalangsa, éra/isin, dan kanyerian. Pada Wawacan Siti Permana, tidaak ditemukan adanya manggalasastra, yang jadi pengantar atau pembuka pada wawacan ini menceritakan keadaan alam di Désa Cigéréléng yang sedang mengalami kesedihan, suara si Tumang menjadi ciri datangnya keburukan (sasalad), masyarakat di Cigéréléng terserang penyakit, hingga kepala desa meninggal dunia, yaitu ayahnya Nyi Permana. Kolofon pada Wawacan Siti Permana, ditemukan titimangsa mengenai 
tamatnya mengarang Wawacan Siti Permana, saperti pada jaman perang Itali dan Absinia (Ethiopia) yang berlangsung ketika perang dunia ke-2 II pada bulan Oktober 1935 sampai Mei 1936. Perang karajaan antara Italia (Regno d'Italia) dan kekaisaran Ethiopia

\section{Pembahasan Antropologi Sastra}

Antropologi sastra pada Wawacan Siti Permana yang dianalisis, meliputi: a) sistem kepercayaan, b) sistem kemasyarakatan/organisasi sosial, c) sistem ilmu pengetahuan, d) bahasa, e) sistem mata pencaharian hidup, f) sistem peralatan hidup dan teknologi, dan g) kesenian

Wawacan Siti Permana telah dipengaruhi oleh Islam, terlihat dari sistem kepercayaan, sistem kemasyarakatan dan ditemukannya bahasa Arab. Sistem kepercayaan pada Wawacan Siti Permana adalah adanya istilah-istilah keagamaan saperti magrib, Qur'an dan Allah, adanya istilah terhadap mahluk gaib saperti jin, iblis dan sétan, serta adanya adat kebiasaan yang berkaitan dengan siklus kehidupan saperti adanya ijab-kabul dan yang berkaitan dengan kegiatan kehidupan saperti jenazah yang dimandikan dan mengajikannya. pada sistem kemasyarakatan terdapat sebutan haji-haji.

Bahasa pada Wawacan Siti Permana yang ditemukan mengenai bahasa Sunda, basa Indonésia, bahasa Arab, gaya bahasa, dan babasan paribasa Sunda. Bahasa Sunda yang digunakan adalah ragam bahasa halus (lemes), bahasa sedang (loma), dan bahasa cohag atau kasar. Bentuk ragam bahasa lemes terbagi jadi ragam bahasa hormat untuk diri sendiri dana ragem bahasa hormat untuk orang lain. Bahasa Indonésa yang digunakan pada Wawacan Siti Permana terdapat 7 kata, yaitu kecuali, cuci muka, nékad, baru, tangan, dan tanda mata. Wawacan Siti Permana juga dipengaruhi oleh serapan dari bahasa Arab, ini terlihat dari ditemukannya beberapa kata serapan, di antaranya kata Allah, Nabi, bismillah, innalillahi, asar, dan magrib. Gaya bahasa yang ditemukan adalah gaya bahasa babandingan/ngupamakeun (simile), gaya bahasa kaleuleuwihi (hiperbola), dan gaya bahasa mijalma (personifikasi). Babasan paribasa yang ditemukan saperti sanés nyiduh ka langit dan belang bayah gindi pikir.

Sistem organisasi kemasyarakatan pada Wawacan Siti Permana ditemukan yang berkaitan dengan lingkungan keluarga dan yang ada di lingkungan masyarakat. Di lingkungan keluarga terdapat kata ibu/ema/indung/, mantu, nini, ama, putra, biangna, sadérék, baraya, akiaki, sepuh, salaki, engkang, enung, bojo, padmi, carogé, rama, ujang, alo, éyang, emang, anak, raka, rayi, dan embi. Di lingkungan masyarakat terdapat kata ménak, haji-haji, bésan, randa, nonoman, agan, para mitra, santri, jawara, bujang, rumajaputri, parawan, murid, dan ratu.

Sistem ilmu pengetahuan pada Wawacan Siti Permana meliputi alam, tumbuhan (tutuwuhan), binatang (sasatoan), warna, istilah bilangan, nama penyakit, bagian-bagian tubuh manusia, nama makanan (kadaharan), dan pakaian. 1) Alam ditemukan adanya kata emas, berlian, cahaya, langit, air (cai), bintang, pasir, gunung, batu, sungai (walungan), leuweung, reuma, kayu, angin, bumi langit, basisir, haseup, daratan, duyung, dunia, hujan, jurang, dinar, poyan, ceudeum, jambrud, samagaha, dan madu. 2) Tumbuhan yang ditemukan digolongkan pada buah-buahan (bungbuahan), bunga (kembang), dan pepohonan (tatangkalan). a) yang termasuk kedalam buah-buahan yaitu buah loa, salak, anggur, lampeni, pasitan, kapundung, ganas, cau, hawuan, kacapi, rambutan, kadongdong, kupa, gandaria, ménténg, kadu, limus, samangka, ceuri, parahulu, pining, nangka, dukuh dan manggu. b) yang termasuk kedalam nama bunga adalah bunga malati, érmawar, 
malati susun, kacapiring-mandakaki, srigading, campaka mulya, tongkéngculan-cakra-cikri, sedep malem, ros, dan tanjung. c) yang termasuk pepohonan adalah lontar, caringin, jati, dan haur duri. Nama hewan yang ditemukan yaitu piit, jogjog, anjing, kalong, pacikrak, merak, sireum, kadal, rambetuk, lasun, japati, cakcak, hayam, lauk, ulat, munding, naga, heulang, lutung, babi, dan kebo. 3) Warna yang ditemukan yaitu warna putih (bodas), merah (beureum), hitam (hideung), dan ungu (wungu). 4) bagian tubuh manusia yang ditemukan adalah halis, biwir, curuk, tarang, ubun-ubun, sungsuam, ramo, rambut/buuk, panangan/ leungeun/tangan, gado, mata panon/soca, getih, pangambung/irung, jajantung, bayah, sirah, tulang, daging, ceuli, pipi, dada, raga, sandi, kulit, harigu, dan dampal suku. 5) Istilah bilangan terbagi menjadi istilah bilangan yang menunjukkan jumlah dan istilah bilangan yang menunjukkan tingkatan. Istilah bilangan yang menunjukkan jumlah adalah tilu, hiji, dua, tilu, opat, salikur, dua puluh, tujuh rewu perak, saprapat dan sarewu. Istilah bilangan yang menunjukkan tingkatan seperti jam 10, kadua, dan tujuh paturunan. 6) Nama penyakit yang ditemukan yaitu muriang, panas tiris, asup angin, lalieur lalanjung, sawan, dan owah. 7) Nama makanan yang ditemukan, yaitu biskuit, manisan, salem, sardéncis, béas, sambara dapur, totongkol, loang, bilis, tanggiri, pépéték, banyar, tanjan, balida, teri, hurang, cumi-cumi dan goréng bawang. 8) Cara berpakaian pada Wawacan Siti Permana seperti untuk lelaki menggunakan ketu héjo, celana hitam pangsi tibét, baju gobroh nyorén balati, dibeubeur $k u$ samping, nyalindangkeun anduk, cingcin loklak dina curuk kiri, kandelna sapatlot, maké geulang taliarus gedé, nyeupah beuki teu kantun sisig, bari udud deui, sarutu cap gunung. keur lalaki anu ngiring mah moal béda saciptaan, lalaki maraké dasi, jasna meureun gobardin, calanana saput kayu, réa nu maké lancer, bendo citak anu limit, hayang tambah gandang maké kaca mata. Yang dipakai oleh perempuan, yaitu kutang poplin kaway Paris, selain dari itu, memakai sinjang gejed menggunakan jepit, selop jéngké sanggul Bandung, salindang tila nyacas, saputanganna pantasi. Melihat dari cara berpakaian orang Sunda pada Wawacan Siti Permana, terlihat bahwa sudah dipengaruhi oleh budaya Barat.

Kasenian yang terdapat pada Wawacan Siti Permana yaitu réog angklung, tanji/tanjidor, gamelan, dan lisung dulag/dugdug. Kasenian tanjidor biasanya dipentaskan di daerah seperti Betawi dan Pantura atau basisir. Selain itu, terdapat juga makanan yang merupakan hasil laut seperti sardéncis, totongkol, tanggiri, pépéték, teri, hurang, dan cumicumi.

Sistem mata pencaharian pada Wawacan Siti Permana dibagi menjadi dua, yaitu pada lembaga dan perilaku (paripolah). Mata pencaharian pada lembaga yaitu lurah, pulisi, bupati, jurutulis, dokter, mantri ulu, dan hakim. Mata pencaharian yang termasuk perilaku yaitu ahli tani/patani, padagang, dukun, gandékna, tukang doa, juru sihir, bangsat, tukang ngajampé, paraji, ema koki, dan ema babu.

Sistem tekhnologi yang ditemukan pada Wawacan Siti Permana, seperti mengenai senjata, peralatan rumah, hiasan badan, tempat duduk, batas rumah, dan teknologi lainnya. Di dalamnya sudah dipengaruhi oleh modernisasi dan terdapat budaya Barat. Senjata yang ditemukan, yaitu bedil, petasan, bom, balati, keris, péstol (pistol) jeung péso (pisau). Peralatan rumah yang ditemukan, yaitu imah, méja, jandéla, tepas, bilik, kaca-kaca, ram kaca, kaca tolét, lampu, pintu, lawang, jamban, sumur, tarajé, damar, dan leuit. Hiasan badan yang diteukan, yaitu baju, samping, salindang sutra, perhiasan, tusuk sanggul, 
sorban, minyak seungit, cingcin, dan pupur. Tekhnologi pada tempat duduk yaitu samak walini. Tekhnologi pada batas rumah menggunakan menggunakan pohon salak dan haur duri, karena tanaman salak dan haur duri memiliki duri, batangnya mérang, kuat serta tebal. Haur duri juga tidakterlalu tinggi sehingga tidak terlalu menutup rumah. Tekhnologi lainnya yaitu menyan, kipas, saku, érloji, kelok, béker, loncéng, artos/ duit, potrét, keretas, koper, dan hampelas.

\section{SIMPULAN}

Wawacan Siti Permana karangan M.K Mangoendikaria (2009) menceritakan seorang wanita yang cantik dan juga baik hatinya, banyak lelaki yang jatuh cinta kepadanya, termasuk Raden Tanu dan juga Prawira, tetapi Tanu menggunakan cara yang tidak baik karena telah mempengaruhi Permana dengan asihan, dan pada akhirnya cinta sejati yang menyatukan Permana dan juga Prawira.

Pupuh yang terdapat pada Wawacan Siti Permana ditemukan berjumlah 10 pupuh dan 526 paragraf, yaitu: 1) pupuh dangdanggula, 2) pupuh asmarandana, 3) pupuh kinanti, 4) pupuh pangkur, 5) pupuh magatru, 6) pupuh sinom, 7) pupuh mijil, 8) pupuh maskumambang, 9) pupuh lambang, dan 10) pupuh pucung.

Banyak nilai-nilai yang sangat penting terdapat pada Wawacan Siti Permana, seperti: a) struktur formal terdapat guru lagu dan guru wilangan yang sesuai dengan patokan pupuh dan yang tidak sesuai dengan patokan pupuh; watek/karakter pupuh seperti kasmaran, sedih, pépéling, lucu, ambek (marah), dan nganti-nganti (menanti); Sasmita pupuh seperti manis, mamanisna, aranom, sinom, kinanti, gumusti, dikanti, magatru, kapungkur-pungkur, tukang, tukangtukang, bijil, mucung, kumambang, dan lambang, b) struktur naratif yang meliputi tema cerita, galur cerita, motif cerita, tokoh cerita, latar cerita, manggalasastra dan kolofon, c) antropologi sastra yang meliputi sistem kepercayaan, sistem kemasyarakatan/organisasi sosial, sistem ilmu pengetahuan, bahasa, sistem mata pencaharian hidup, sistem peralatan hidup dan teknologi, dan kesenian

\section{PUSTAKA RUJUKAN}

Ahmadi, Anas. (2010). Potret Manusia Indonesia dalam Cerpen "Derabat" Karya Budi Darma: Kajian Strukturalisme Genetik. Jurnal Parafrase, Vol 10, No 01, hal. 40-48.

Astutik, Ika Dwi. (2012). Budaya Jawa dalam Novel Tirai Menurun Karya NH. Dini (Kajian Antropologi Sastra). Jurnal Sapala terbit 2013, Sastra Indonesia-FPBS-UNS, Vol 01, No 01, hal. 0-11.

Istiqomah, Siti. (2015). Fenomena Batu Akik Pada Masa Orde Baru di Masyarakat Gunung Kidul dalam Novel Maya Karya Ayu Utami: Kajian Antopologi Sastra. Jurnal Sastra Indonesia, Vol 4, No 5, hal. 1-10.

Koswara, Dedi. (2011). Racikan Sastra: Pangdeudeul Bahan Perkuliahan Sastra Sunda. Bandung: JPBD-FPBSUPI.

Mahmud, Kusman K. (1987). Sastra Indonesia dan Daerah: Sejumlah Masalah. Bandung: Angkasa.

Mangoendikaria, M.K. (2009). Wawacan Siti Permana. Bandung: PT Indahjaya Adipratama.

Moriyama, Mikihiro. (2013). Semangat Baru: Kolonialisme, Budaya Cetak, dan Kesusastraan Sunda Abad Ke-19. Jakarta: Komunitas Bambu.

Nazir, Moh. (2005). Metode Penelitian. Bogor: Ghalia Indonesia.

Pradopo, Rachmat Djoko. (2001). Puisi Pujangga Baru: Konsep Estetik, Orientasi, dan Strukturnya. Jurnal Humaniora, Vol XIII, No 1, hal. 5563.

Putranto, Andi. (2003). Pandangan Masyarakat Gunung Kidul Terhadap 
Pelarian Majapahit Sebagai Leluhurnya (Kajian atas Data Arkeologi dan Antropologi). Jurnal Humaniora, Vol 15, No 2, hal. 224233.

Sudaryat, Yayat, dkk. (2007). Makaya Basa Sunda: Pangdeudeul Pangajaran Basa jeung Sastra Sunda. Bandung: Sonagar Préss JPBD-FPBSUPI.

Suhartono, dkk. (2010). Cerita Rakyat di Pulau Mandangin: Kajian Struktural Antropologi Claude Lévi Strauss. Vol, 23, No 4, hal. 304-311. Jurusan Bahasa dan Sastra Indonesia-FPBSUNS
Sukmadinata, N.S. (2012). Métode Penelitian Pendidikan. Bandung: PT Remaja Rosdakarya.

Suyatna, A. (2002). Pengantar Metodologi Pendidikan dan Pengajaran Bahasa. Bandung: Departemen Pendidikan Nasional-UPI-FPBS-JPBD.

\section{UCAPAN TERIMA KASIH}

Ucapan terima kasih saya sematkan kepada Allah SWT karena telah memberi kesehatan lahiriah maupun batiniah sehingga dapat menyelesaikan artikel ini. Terima kasih juga saya ucapkan kepada kedua orang tua saya, para dosen, dan sahabat-sahabat saya yang telah mendukung dan membantu menyelesaikan karya tulis ini. 